\title{
Estimation of annual harvested runoff at Sulaymaniyah Governorate, Kurdistan region of Iraq
}

\author{
Saleh Zakaria ${ }^{1,2}$, Yaseen T. Mustafa ${ }^{3}$, Diary A. Mohammed ${ }^{4}$, Salahalddin Saeed Ali ${ }^{4}$, \\ Nadhir Al-Ansari ${ }^{1^{*}}$, Sven Knutsson ${ }^{1}$ \\ ${ }^{1}$ Department of Civil, Environmental \& Natural Resources Engineering, Lulea University of Technology, Lulea, Sweden; \\ ${ }^{*}$ Corresponding Author: nadhir.alansari@1tu.se \\ ${ }^{2}$ Department of Water Resources Engineering, University of Mosul, Mosul, Iraq \\ ${ }^{3}$ University of Zakho, Duhok, Iraq \\ ${ }^{4}$ University of Sulaimani, Sulaimani, Iraq
}

Received 7 November 2013; revised 7 December 2013; accepted 14 December 2013

Copyright (C) 2013 Saleh Zakaria et al. This is an open access article distributed under the Creative Commons Attribution License, which permits unrestricted use, distribution, and reproduction in any medium, provided the original work is properly cited. In accordance of the Creative Commons Attribution License all Copyrights (C) 2013 are reserved for SCIRP and the owner of the intellectual property Saleh Zakaria et al. All Copyright (C) 2013 are guarded by law and by SCIRP as a guardian.

\begin{abstract}
Kurdistan Region (KR) of Iraq has suffered from the drought period during the seasons 20072008 and 2008-2009 that affected the human and economic activities of the region. Macro rainwater harvesting (Macro RWH) is one of the techniques that can ensure water availability for a region having limited water resources. This technique is based on Soil Conservation ServiceCurve Number (SCS-CN) method and the Watershed Modeling System (WMS) was used to estimate the runoff. Rainfall records of Sulaymaniyah area for the period 2002-2012 were studied and an average season was selected (2010-2011). The results of the application of the WMS model showed that about 10.76 million cubic meters could be harvested. The results also showed that the quantity of the harvested runoff was highly affected by rainfall depth, curve number values, antecedent moisture conditions (AMC) and the area of the basins.
\end{abstract}

Keywords: Macro Rainwater Harvesting;

Sulaymaniyah; Kurdistan Region; Iraq

\section{INTRODUCTION}

Iraq is a part of the arid and semi-arid area of the Middle East and North Africa (MENA) region. The climate of the region is characterized by its fluctuation in rainfall and periods of droughts [1]. Recently, Iraq is experiencing water shortages despite the presence of the Tigris and Euphrates Rivers [1-3].
During the past few years, north Iraq (especially Kurdistan Region) experienced a period of draught. As a result, many of the inhabitants left their villages and migrated to big cities [4].

Water scarcity issue is becoming more serious due to several factors. Among them is the increasing water demand, high population rate, effect of global warming, plusmiss management and planning of the water resources during the last four decades. In addition, water policies of neighboring countries enforced another burden where huge dams were built on the upper parts of the Tigris and Euphrates Rivers in Syria and Turkey. And this led to the reduction of the flow rate of both rivers inside of Iraq [1-3].

Recent research indicates that Iraq will face more challenges in future, where the water shortage problem is becoming more serious with time $[1,2,5,6]$, and Tigris and Euphrates Rivers are expected to be dry in 2040 [5]. The expected discharge in the year 2025 of the two rivers will be tremendously decreased [4] (Figure 1).

In view of the above, new judicious techniques, methods and strategies for water conservation should be adopted in the management and planning of water resources [7]. United Nations [5] stated that "Iraq's water resource management will play a prominent role in contributing to the country's efforts to eradicate poverty and hunger, reduce child mortality and ensure environmental sustainability". Prinz and Singh [7] indicated that water development and management should be based on a participatory approach, involving users, planners and policy-makers at all levels. Due to limited water availability in the region, the agricultural strategy that should be adopted is represented by maximizing the yield per unit 


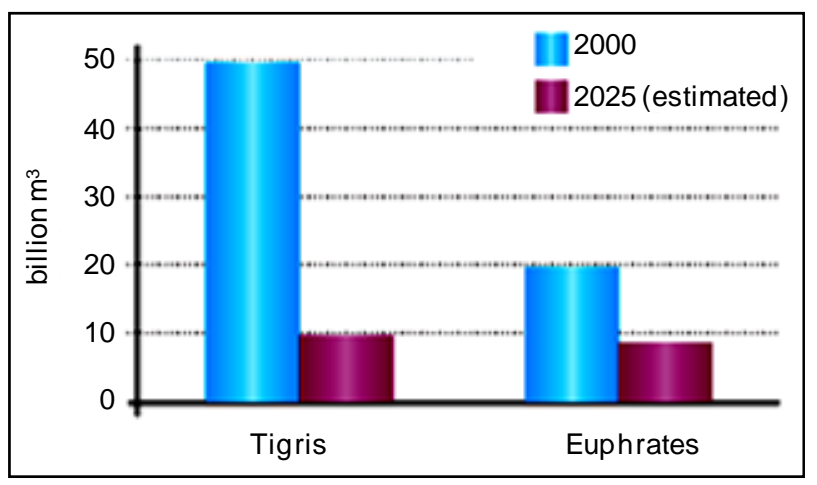

Figure 1. Average discharge of Tigris and Euphrates in the year 2000 and the expected discharge in the year 2025, (source UNDP, 2011, [4]).

of water used and not the yield per unit of land [8] as well as the use of non-conventional water resources $[2$, $3]$.

\subsection{Validity of Rain Water Harvesting}

Practically, rainwater harvesting (RWH) might be one of the good solutions for the problem. This technique was used since 9000 years ago and some of the old schemes are still operating [9-12]. This technique is gaining popularity recently [13]. Siegert [14] defined RWH as "the collection of runoff for its productive use". Prinz [9] indicated that the annual rainfall $(100-700 \mathrm{~mm})$ of low cost water harvesting might give an important new water source. The main objective of RWH is to increase the availability of water but not its amount. Furthermore, water harvesting is based on runoff (the excess rainwater) producing and runoff receiving areas (natural catchment areas) [9]. The factors such as amount of rainfall and its distribution, land topography, soil type and soil depth, and local socio-economic may represented the main factors that affect the water harvesting $[15,16]$.

There are good literature reviews of RWH, especially micro rainwater harvesting. Boers [17] reviewed some 170 articles published between 1970 and 1980 concerning Micro catchment water harvesting of small-scale catchments (area less than $1000 \mathrm{~m}^{2}$ ) and its potential application for crop production. Another type of harvesting rainwater is Macro RWH which is more effective to augment water from large catchment area (many square kilometers with slope ranged between 5\% - 50\%) [9]. In this technique, dams are constructed and water from harvested runoff (the excess rainwater) is stored in surface reservoir in order to be supplied later when required [18-22]. The potential of RWH is widely cited [23]. The subsequent studies indifferent parts of the world had explained that RWH systems had proven to be an effective technique achieving a new water source that can be used for several purposes, led to an increase in crop production [24-
26], and reduced the risk of drought [27-29]. The rainwater harvesting has the ability to ensure availability of water for the region [30] as well. The effective management of RWH becomes more interesting phase of water resource management strategies in most countries that are suffering from the problem of water scarcity [31].

Soil Conservation Service Curve Number (SCS-CN) is one of the important approaches that help to study the rainfall-runoff relationship of watershed. The main purpose for this method is to determine direct runoff from individual daily rainfall storm and it is widely used by many researchers [32]. Saber et al. [33] were among the researchers who have studied the runoff of watershed within Arabic countries using physical distributed hydrological model and applied it in the selected Wadis based on the SCS-CN method. Their purpose was investigating the differences of runoff amounts in space and time through comparative studies of some important selected basins (Wadi Al-Khoud in Oman having an area of 1874.84 $\mathrm{km}^{2}$, wadiGhat in Saudi Arabia having an area of 649.55 $\mathrm{km}^{2}$, and WadiAssiut in Egypt having an area of 7109 $\mathrm{km}^{2}$ ). They concluded that the applied model is applicable to estimate the surface runoff in arid region. Al-Zubi et al. [34] carried out their research in a semi-arid area of WadiMuheriwir which is located in the Eastern part of Jordan. They estimated the runoff by applying the SCS$\mathrm{CN}$ method using available rainfall data for the period 1976-2006. They concluded that the curve number for WadiMuheriwir is about 80 , the average runoff is about 0.063 million cubic meters, and the rainwater harvesting technique is suitable for agricultural activities in WadiMuheriwir.

\subsection{Application of RWH in Iraq}

Other studies that conducted inside Iraq, such as Šimák [35] adopted SCS-CN method to estimate the basin runoff in order to estimate design flood wave characteristics for the basin of AshiBaram (Qutabian) dam. The dam site is under planning, located between Chwarta and Baneh towns, in Iraq on the border with Iran. The project aims to develop eastern part of Sulaymaniyah Governorate by creating a reservoir for irrigation purpose. The drainage area is estimated to be $1340.7 \mathrm{~km}^{2}$. The whole area is a part of massive mountain range Zargos which extends all over the north eastern part of Iraq. Thus, Šimák [35] adjusted the curve number values for the slope using Williams' formula [36] (for more details see [37, 38]). Mohammed [39] investigated water harvesting in Erbil Governorate, Kurdistan region of Iraq using geographic information system and remote sensing in order to detect the suitable sites for RWH. He concluded that SCS-CN method was applied using mean annual rainfall of the period (2000-2011) in Erbil area to estimate the runoff depth. The results showed that there was a signi- 
ficant amount of annual runoff which could be harvested. The minimum and maximum runoff depth was about 103 and $1000 \mathrm{~mm}$ at north and south Erbil area respectively.

Zakaria et al. [18,19] studied Macro RWH technique based on SCS-CN method, in North West Iraq. Two studies were carried out at north and east Sinjar Mountain respectively for the period 1990-2009. The areas are characterizes by semi-arid climate. The results indicated that there was a significant amount of yearly runoff (0.6 42.4) $\left(10^{6} \mathrm{~m}^{3}\right)$ for the study period at north Sinjar. Implementation of Macro RWH in the Northern and Eastern Sinjar District gave encouraging results leading to an increase of irrigated area.

Zakaria et al. [21] investigated the potential of RWH and its ability to support the wheat yield (bread and durum) under various rainfall conditions in the rain-fed of same Northern Sinjar District (Iraq) for the study period 1990-2009 using three supplemental irrigation (SI) scenarios $(100 \%, 75 \%$, and $50 \%$ of full irrigation requirement). They concluded that using rainwater harvesting technique gave total volume of harvested runoff that can be considered for irrigation practices, which reached up to $42.4,25.1,0.60,10.9\left(10^{6} \mathrm{~m}^{3}\right)$ during 1995-1996, 1996-1997, 1998-1999, and 2001-2002, respectively.

Zakaria et al. [30] and Al-Ansari et al. [40] investigated rainwater harvesting at north east of Iraq, in Koysinjaq (Koya), Erbil Governorate. The study aimed to discover the potential of the area for rainwater harvesting. The results showed that the application of Macro RWH would provide a new source for water. The annual volume of water that can be harvested from all selected basins ranged from 14.83 to $80.77\left(\times 10^{6} \mathrm{~m}^{3}\right)$ for the study period (2002-2011).

Zakaria et al. [31] identified twenty two basins around Koya, Erbil Governorateat north east of Iraq, as the catchment area for the application of RWH technique in order to evaluate the total runoff from whole Koya area that may be harvested instead of being lost to the near area. Two consecutive adjustments for the curve number were considered. The first was for the antecedent moisture condition (AMC) and the second was for the slope. These adjustments increased the total resultant harvested runoff up to $79.402 \times 10^{6} \mathrm{~m}^{3}$.

In view of the good results of RWH, it was considered in this research to provide a new source of water for Sulaymaniyah city.

\section{METHODOLOGY}

Watershed modeling system (WMS) was used to find out the quantity of rainfall that can be harvested in Sulaymaniyah area. To apply the model, then the sites of the dams that will capture the runoff in different catchments were identified. This was achieved using the Digital Elevation Model (DEM) of the study area with Global
Mapper model. In the site selection process, minimum dam's cross section were considered to minimize the constructions cost. The next step was finding the curve numbers $(\mathrm{CN})$ values for normal, dry and wet conditions based on the information obtained from land use map, soil type and the selected basins. WMS with Sulaymaniyah's DEM was applied using CN values, and daily rainfall data, for all individual selected basins. The runoff volumes were estimated based on SCS-CN method. The time of concentration for selected basins was estimated, considering single rainfall storm on the study area. Then the suitable storm type (I, 24-hour Storm) was used. The hydrograph time increment of 0.1 was set with WMS, and the volumes of runoff for the selected basins were calculated.

Furthermore, the main formula for SCS-CN method as described by the Soil Conservation Service, 1972 for the relationships between precipitation and runoff is expressed as:

$$
\begin{aligned}
& Q=\frac{(p-0.2 S)^{2}}{P+0.8 S} \text { if } P>0.2 S \\
& Q=0 \text { if } P \leq 0.2 S \\
& Q=\left(\frac{1000}{C N}-10\right) \times 25.4
\end{aligned}
$$

where:

$Q=$ the direct runoff or rainfall excess ( $\mathrm{mm})$.

$P=$ the storm rainfall $(\mathrm{mm})$.

$S=$ the maximum potential soil water retention $(\mathrm{mm})$.

$C N=$ the curve number (dimensionless).

With SCS-CN method, the soil was classified into four hydrological soil groups A, B, C and D considering the basin wetness index i.e. the antecedent moisture condition (AMC) which had been classified into three classes AMC I, AMC II and AMC III, representing dry, normal (average) and wet conditions. In order to specify each class, the antecedent rainfall amount of five-day and season category (dormant) were considered.

For the Soil Conservation Service, 1972 (SCS-CN) method, the tabulated curve number is equal to CNII, for normal (average) conditions, and modified for dry and wet conditions, as explained by Chow et al. [41] through the following equations:

$$
C N_{I}=\frac{4.2 \times C N_{I I}}{10-0.058 \times C N_{I I}}
$$

In which:

$C N_{I}=$ Curve number for dry condition.

$$
C N_{I I I}=\frac{23 \times C N_{I I}}{10+0.13 \times C N_{I I}}
$$

In which:

$C N_{I I I}=$ Curve number for wet condition. 
Williams [36] developed an equation to adjust the curve number to a different slope [37,38]:

$$
\begin{aligned}
& {\left[C N_{I I}\right]_{S L P}=\frac{\left(C N_{I I I}-C N_{I I}\right)}{3}} \\
& \times[1-2 \times \exp (-13.86 \times S L p)]+C N_{I I}
\end{aligned}
$$

where:

$\left[C N_{I I}\right]_{S L P}=$ the curve number for average condition adjusted for the slope.

$S L P=$ the average fraction slope of the basin.

More details about the methodology used for this research are well documented by $[18,19,22,31]$.

\subsection{Study Area}

Sulaymaniyah is the biggest Governorate of Kurdistan Region of Iraq, located north east of Iraq on a border with Iran of geographic coordinate Latitude and Longitude $35^{\circ} 33^{\prime} 40^{\prime \prime} \mathrm{N}$ and $45^{\circ} 26^{\prime} 14^{\prime \prime} \mathrm{E}$ respectively. It contains ten districts. The elevation of Sulaymaniyah center is about $830 \mathrm{~m}$ above sea level. Four Iraqi Governorates border Sulaymaniyah from the north, west, and south which are Erbil, At-Ta'mim, Slahad-Din and Diyala (Figure 2).

Sulaymaniyah Governorate is witnessing a state of rapid growth and development where it represents the cultural capital of Kurdistan Region of Iraq. The population of Sulaymaniyah is about 723,170 people.

The study area consist of five separated basins with total area of $176.79\left(\mathrm{~km}^{2}\right)$, located about $7(\mathrm{~km})$ North West of Sulaymaniyah city. According to Buringh [42] the soil of the study area is of three main types $(37,38$, and 39) as shown in Figure 3. Simak [35] indicated that the last two soil types can be identified as C, and D of the Hydrologic Soil Group according to the United States Department of Agriculture Natural Resources Conservation Service (Conservation Engineering Division 1986). Buringh [42] classified the soil types 37 as great Soil group of Chestnut soils and the soil type is silty clay, having a dark brown color, friable surface soil, usually with $1 \%-4 \%$ of organic matter and less than $9 \%$ lime. The properties of the selected basins at Sulaymaniyah Governorate were estimated (Table 1).

\subsection{Sulaymaniyah Climate}

Average monthly climatic elements for the study period (2002-2012) for Sulaymaniyah city are tabulated in Table 2 as obtained from Sulaymaniyah meteorological station.

The geographic location of Sulaymaniyah Governorate imposed a dry and warm summer for the period June, July, and August, with temperature of $31.5\left({ }^{\circ} \mathrm{C}\right)$ as an average summer temperatures for the studied period. The city is usually windy during winter and there are spills of snow falling sometimes. This season extends from December till February. However, the temperature in the winter season is about $7.6\left({ }^{\circ} \mathrm{C}\right)$. The average relative humidity for summer and winter are $25.5 \%$ and $65.6 \%$ respectively, while the evaporation reached $329.5(\mathrm{~mm})$ in summer and $53(\mathrm{~mm})$ in winter where the average wind speed in winter $1.2(\mathrm{~m} / \mathrm{sec})$ and little bit more in summer $(1.8 \mathrm{~m} / \mathrm{sec})$. Sunshine duration reaches 5.1 and $10.6(\mathrm{hr})$ in winter and summer respectively. Rainfall season starts

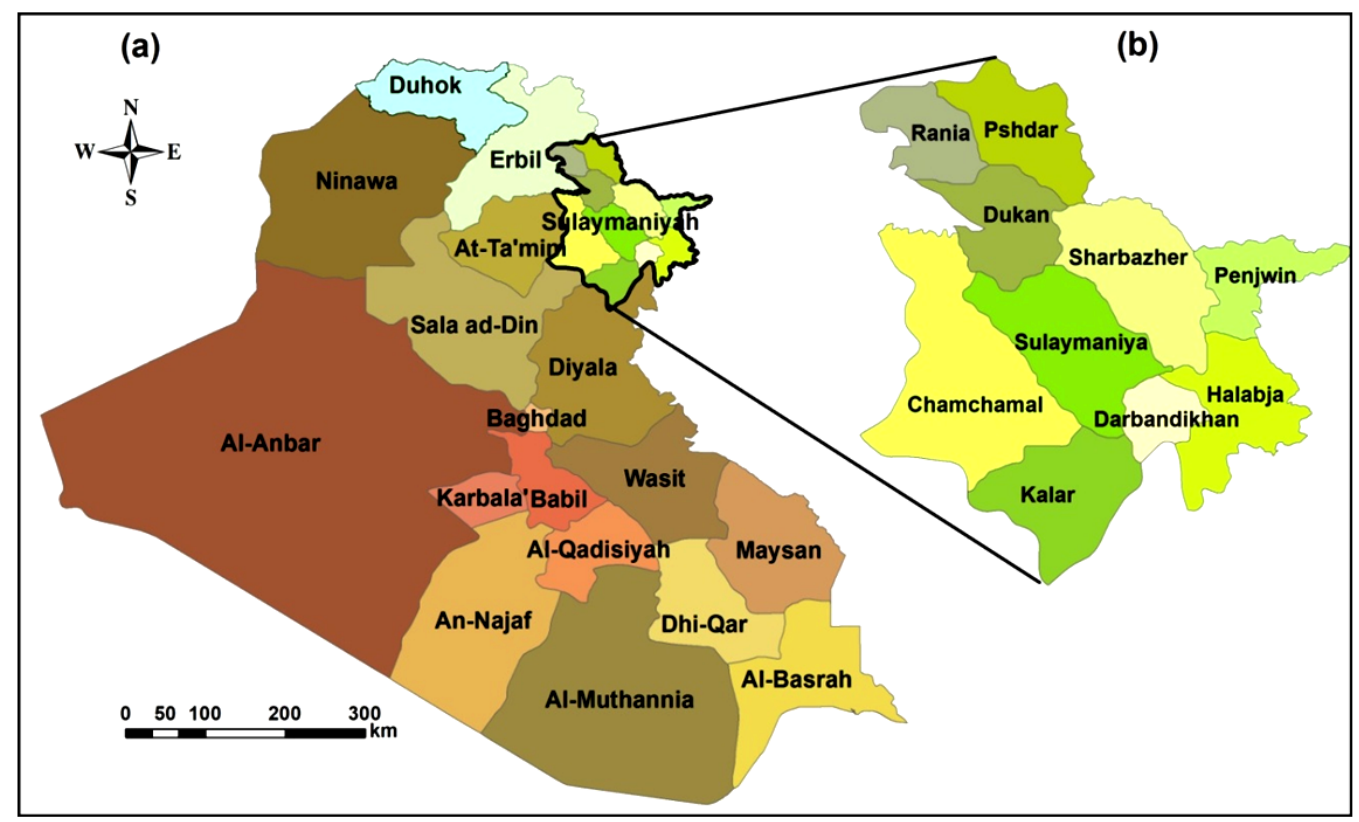

Figure 2. Map of Iraq with enlarge view of the ten districts of Sulaymaniyah governorate. 


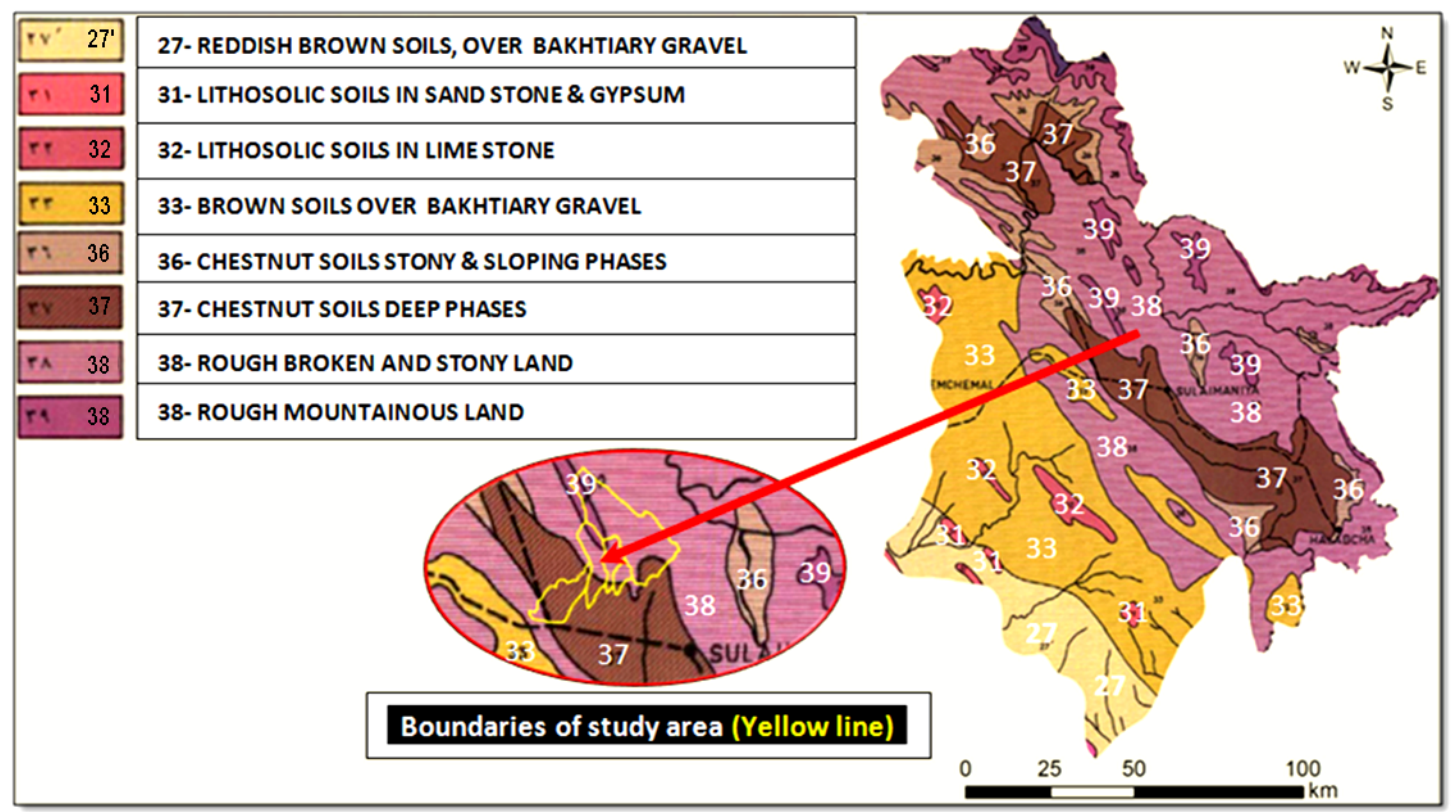

Figure 3. Soil map of Sulaymaniyah governorate with boundaries of study area, source: [42].

Table 1. Properties of the selected basins at Sulaymaniyah governorate.

\begin{tabular}{cccccccc}
\hline Basin & $\begin{array}{c}\text { Basin Slop } \\
(\mathrm{m} / \mathrm{m})\end{array}$ & $\begin{array}{c}\text { Basin Area } \\
\left(\mathrm{Km}^{2}\right)\end{array}$ & $\begin{array}{c}\text { Time of Concentration } \\
(\mathrm{hr})\end{array}$ & $\begin{array}{c}\text { Length } \\
(\mathrm{km})\end{array}$ & $\begin{array}{c}\text { Elevation } \\
(\mathrm{m})\end{array}$ & \multicolumn{2}{c}{ UTM Coordinate } \\
\cline { 5 - 8 } & 0.2837 & 98.08 & 2.14 & 18.137 & 1179 & 534704 & 3944815 \\
$\mathbf{1}$ & 0.251 & 13.87 & 1.02 & 7.988 & 1211 & 528567 & 3942854 \\
$\mathbf{3}$ & 0.1848 & 7.35 & 0.61 & 4.858 & 1098 & 530133 & 3942576 \\
$\mathbf{4}$ & 0.2202 & 25.83 & 1.3 & 12.131 & 1182 & 525903 & 3940711 \\
$\mathbf{5}$ & 0.0688 & 31.66 & 1.54 & 8.587 & 855 & 522711 & 3939177 \\
\hline
\end{tabular}

Table 2. Average monthly values of the climatic elementsat Sulaymaniyah station for the study period 2002-2012.

\begin{tabular}{ccccccc}
\hline Month & Temperature $\left({ }^{\circ} \mathrm{C}\right)$ & Humidity $(\%)$ & Evaporation $(\mathrm{mm})$ & Wind $(\mathrm{m} / \mathrm{sec})$ & Sunshine $(\mathrm{hr})$ & Rainfall $(\mathrm{mm})$ \\
\hline Oct. & 22.3 & 43.8 & 141.6 & 1.10 & 7.1 & 38.22 \\
Nov. & 14 & 57.2 & 72.6 & 0.90 & 6.3 & 63.50 \\
Dec. & 8.4 & 61.2 & 51.4 & 1.10 & 5.3 & 81.80 \\
Jan. & 6.5 & 70.3 & 53.4 & 1.20 & 5.2 & 124.40 \\
Feb. & 7.8 & 65.4 & 54.1 & 1.20 & 4.8 & 125.10 \\
Mar. & 12.8 & 54.9 & 97.1 & 1.60 & 5.7 & 88.10 \\
Apr. & 17.3 & 55.1 & 132.8 & 1.30 & 6.4 & 95.19 \\
May & 24.0 & 41.6 & 226.4 & 312.4 & 2.00 & 37.89 \\
June & 29.6 & 26.4 & 352.6 & 1.80 & 10.2 & 0.57 \\
July & 31.8 & 25.2 & 323.9 & 1.50 & 10.6 & 0.9 \\
Au.g & 33.2 & 24.9 & 234.7 & 1.30 & 9.9 & 0.02 \\
Sep. & 28 & 28.4 & & & & 1.26 \\
\hline
\end{tabular}

in October at Sulaymaniyah with light rainfall storms and it intensifies during November and continues till May. During the studied rainfall records the driest season was recorded in 2008-2009 of $328 \mathrm{~mm}$ and the maximum rainfall depth was in 2003-2004 of $848 \mathrm{~mm}$. The season 2010-2011 represent the average rainy season of 548.8 $\mathrm{mm}$. Figure 4 shows annual rainfall depths for the study period. 


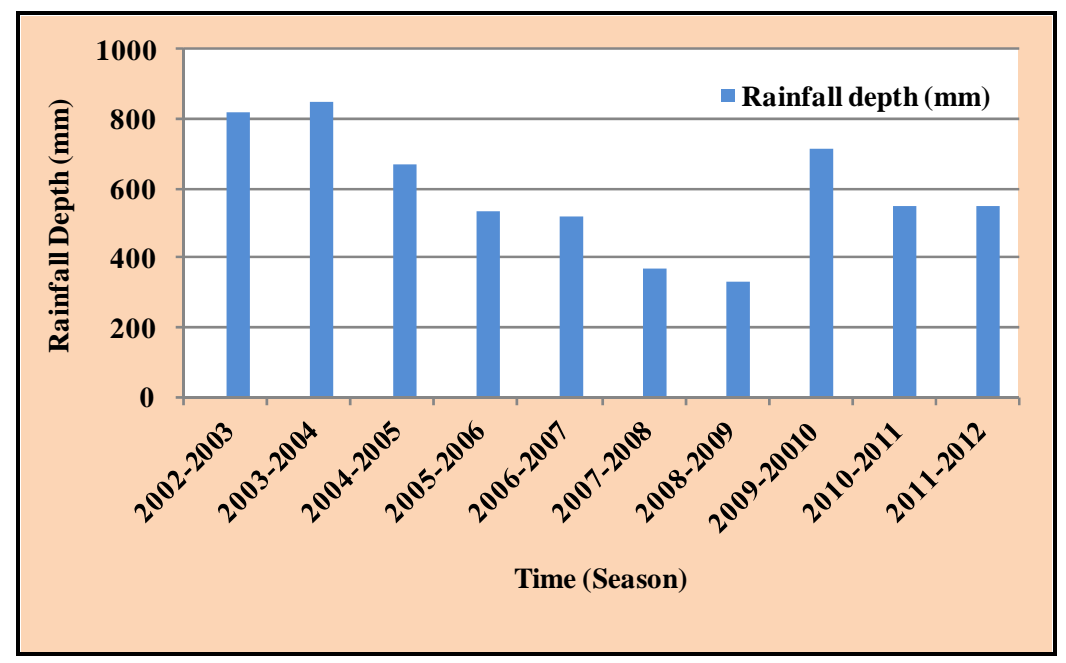

Figure 4. Annual rainfall depths of Sulaymaniyah area for the period (2002-2012).

\subsection{Land Use/Land Cover}

The Land use/land cover (LULC) map of Sulaymaniyah Governorate (Figure 5) was derived from satellite imagery, Landsat 8 that has 11 bands with a $30 \mathrm{~m}$ spatial resolution. Three Landsat images; acquired in 08 June 2013, were used to cover the study area. These images were geometrically and atmospherically corrected. Then, these images were mosaicked and the study area (Sulaymaniyah) masked up from the mosaicked image. Thematic mapping of different LULC classes was achieved through supervised classification using a maximum likelihood approach. For more procedure details of creating the LULC map see previous work [30].

\subsection{Curve Number}

The weighted average $\mathrm{CN}$ values for five selected basins were estimated depending on area of specific land use land cover as a percent of total basin area and calibrated based on AMC for dry, normal (average), and wet conditions depending on the total antecedent rainfall depth of five days as formulated by SCS-CN method. Then CN values were adjusted for slope using Williams' formula [36] for each basin (Table 3).

\section{RESULTS AND DISCUSSION}

In order to simulate the average runoff events in the catchment area of five basins with total area of 176.79 $\mathrm{Km}^{2}$ the season 2010-2011 was selected with total rainfall depth $548.8 \mathrm{~mm}$ which represent the average rainy seasons during the study period 2002-2012. Rainfall depths of the season were ranging from 0.1 to $50.9 \mathrm{~mm}$. The total rainy days were 66 (Figure 6). These rainy days extended along 212 days (length of season 20102011). During the first forty days, the total rainfall depth was $1 \mathrm{~mm}$ that accorded during the $2^{\text {nd }}$ day of the season.
After that, during the $2^{\text {nd }}$ forty days rain began with fluctuating intensities where the rainfall depth ranged between $0.2-29 \mathrm{~mm}$. It should be noted that, at the best, it didn't rain continuously more than three days. After 80 days, it was continuously raining for five consecutive days, but with low intensity, where the total rainfall depth during these five days was just $12.3 \mathrm{~mm}$. Then after 120 days of the rainy season, rainfall started continuously for four days. Total rainfall depth reached 48.6 $\mathrm{mm}$. One hundred and sixty days later, rainfall reached $111.1 \mathrm{~mm}$ in four continuously days and come back after five days to continue for another five continuous days with total depth of $63.8 \mathrm{~mm}$. In the remaining period, till the end of the season, the rainfall subsided with total rainfall depth of $0.2 \mathrm{~mm}$.

To apply the Soil Conservation Service-Curve Number (SCS-CN) method, it should be noted that antecedent moisture conditions (AMC) is considered dry if total five days antecedent rainfall depths is less than 0.5 inch (12.7 $\mathrm{mm}$ ), and the condition is normal if total five days antecedent rainfall depths ranged between 0.5 to 1.1 inch (12.7 to $27.94 \mathrm{~mm}$ ). The condition will be considered wet if the total five days antecedent rainfall depths is more than 1.1 inch $(27.94 \mathrm{~mm})$ [41].

In this research, sixteen rain storms were considered in the season 2010-2011 that may produce runoff. They were classified according to the AMC as follow: five of them to place where the basins were under dry condition, another four occurred where normal conditions dominated the basins, the other seven occurred when the basins were under wet condition.

The distribution of the rainfall events were as follow: On $12^{\text {th }}$ Dec, 2010 (which is the $42^{\text {nd }}$ day of start of the season), a rain storm reached $21 \mathrm{~mm}$; during the same day, the value of summation rainfall depths for the last five days or antecedent moisture conditions (AMC) was 


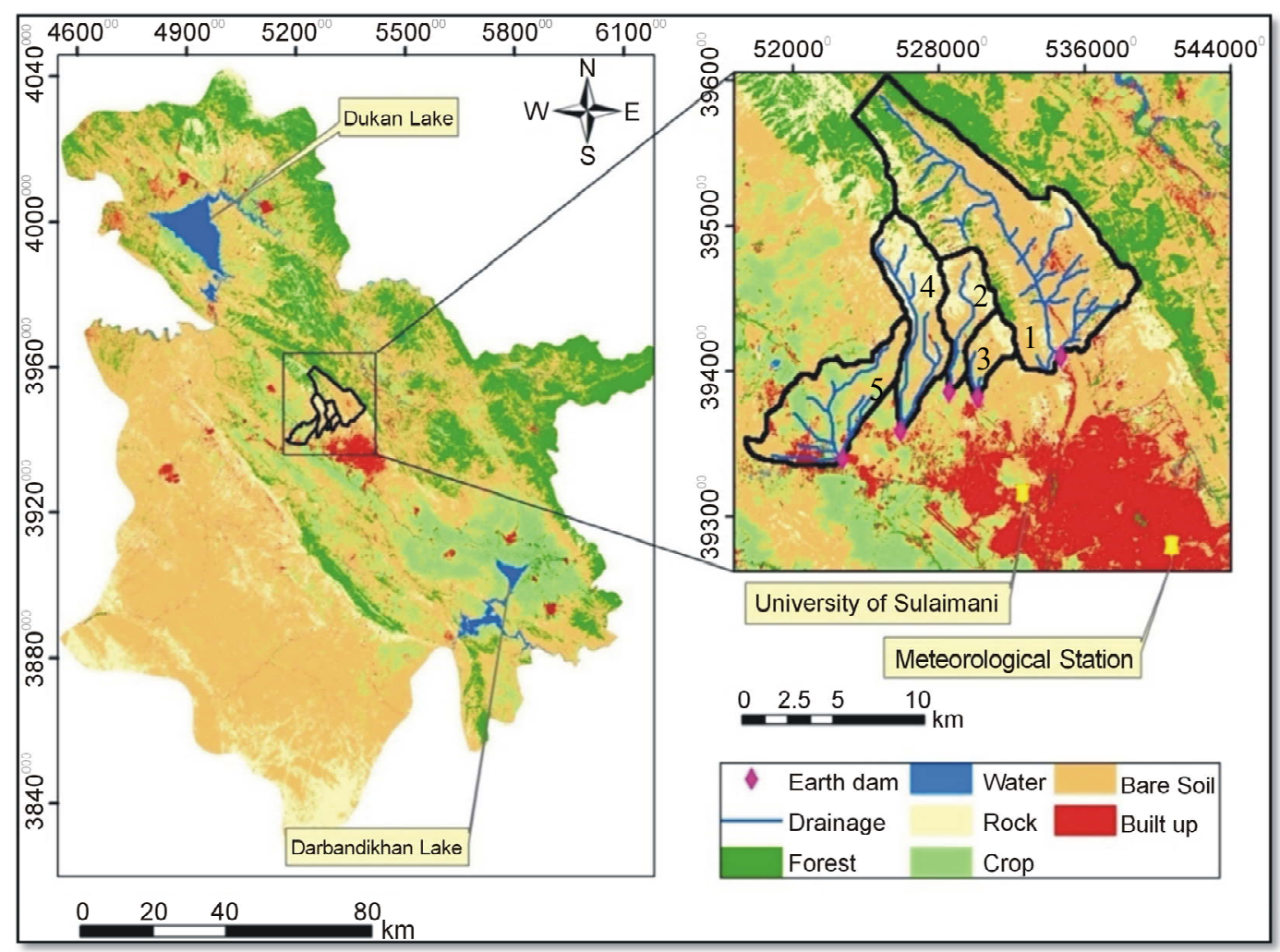

Figure 5. Land use/land cover map of Sulaymaniyah governorate (on left), with enlarge view of study area.

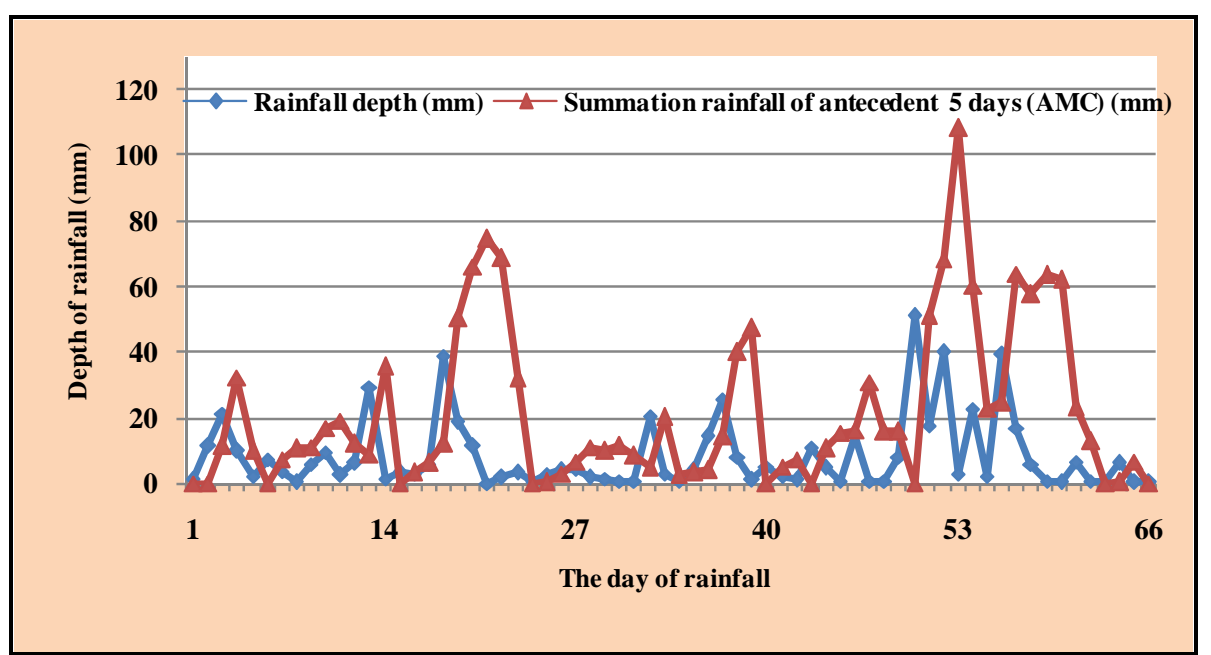

Figure 6. Daily rainfall of the season 2010-2011 with antecedent moisture conditions (AMC).

Table 3. Curve number $(\mathrm{CN})$ values before and after adjustment for slope for the selected basins.

\begin{tabular}{|c|c|c|c|c|c|c|}
\hline \multirow[b]{2}{*}{ Basin } & \multicolumn{3}{|c|}{ Values of CN } & \multicolumn{3}{|c|}{ Adjustment CN values for slope } \\
\hline & $\begin{array}{c}\text { CN-Normal } \\
\left(C N_{I I}\right)\end{array}$ & $\begin{array}{c}\text { CN-Dry } \\
\left(C N_{I}\right)\end{array}$ & $\begin{array}{c}\text { CN-Wet } \\
\left(C N_{I I I}\right)\end{array}$ & $\begin{array}{c}\text { CN-Normal } \\
\left(C N_{I I}\right)\end{array}$ & $\begin{array}{c}\text { CN-Dry } \\
\left(C N_{I}\right)\end{array}$ & $\begin{array}{l}\text { CN-Wet } \\
\left(C N_{I I I}\right)\end{array}$ \\
\hline 1 & 76.3 & 75.5 & 88.1 & 80.1 & 62.8 & 90.2 \\
\hline 2 & 80.1 & 62.8 & 90.3 & 83.3 & 67.7 & 92.0 \\
\hline 3 & 79.1 & 61.4 & 89.7 & 82.1 & 65.8 & 91.3 \\
\hline 4 & 80.4 & 63.3 & 90.4 & 83.4 & 67.9 & 92.0 \\
\hline 5 & 76 & 57.1 & 87.9 & 76.9 & 58.3 & 88.5 \\
\hline
\end{tabular}


$11.2 \mathrm{~mm}$ which implies that the curve number $(\mathrm{CN})$ was under dry conditions. For such conditions, this rain storm did not produce any runoff. The $2^{\text {nd }}$ rainstorm, occurred on the $43^{\text {rd }}$ day, with depth of $9.8 \mathrm{~mm}$, but the basins were under wet condition, where AMC was $32.2 \mathrm{~mm}$ and the storm was capable of producing runoff. Other rainfall events occurred on $76^{\text {th }}, 90^{\text {th }}, 91^{\text {st }}$, and $92^{\text {nd }}$ days of the beginning of the season. The rain depths were 29.3, 38.6, 18.7 and $11.3 \mathrm{~mm}$ and their AMC were 8.7, 11.9, 50.5 and $66 \mathrm{~mm}$ respectively.

This implies that the $\mathrm{CN}$ was considered as dry and normal for the first two rain storms respectively and wet for the last two events. Taking the depth of rain into consideration, the first rain storm produced runoff for all the basins except basin No. 5 (this will be explained later). On the $113^{\text {th }}$ and $127^{\text {th }}$ days of starting season, two rain storms took place having rain depths of 20.2, and 14.2 $\mathrm{mm}$, where dry conditions dominated the basins and AMC reached 4.8, and $3.9 \mathrm{~mm}$ respectively. These two rain storms didn't produce any runoff. On $128^{\text {th }}$ and $159^{\text {th }}$ days of starting season, two rain storms occurred with rain depth of 25.6 and $14.7 \mathrm{~mm}$ with normal AMC (14.2, and 16.1$) \mathrm{mm}$, their runoff reached the outlet of the basins where the harvest reservoir are located. On $171^{\text {st }}$ days of starting season, another rain storm occurred with rain depth of $50.9 \mathrm{~mm}$ and produced runoff under dry conditions, where its AMC was $0.0 \mathrm{~mm}$. Other three rain storms that produced runoff occurred on the following days $172^{\text {nd }}, 173^{\text {rd }}$, and $177^{\text {th }}$ of starting season that they reached $17.4,39.2$, and $22.8 \mathrm{~mm}$ of rain depth. All of them under wet conditions where AMC were 50.9, 68.3, and $60.2 \mathrm{~mm}$. On $181^{\text {st }}$, and $182^{\text {nd }}$ day of starting season, the final two rain storms occurred on $30^{\text {th }}$ April, and $1^{\text {st }}$ May, 2011 with rainfall depths of 39.2 and $16.6 \mathrm{~mm}$ respectively. Their AMC were 24.7 and $63.9 \mathrm{~mm}$ under normal and wet condition respectively.

The rainy season 2010-2011 is a typical season for the application of macro rainwater harvesting technique. In spite the fact that, the total rainfall depth reached 548 $\mathrm{mm}$, the rainfall distribution extremely reflects the characteristics of the semi-arid region of small rainfall depths that was spread through the season with frequent period of fluctuation, and interruption some of the storms occurred in a very close period over four to five consecutively days which reduced and limited the ability of agricultural crop fields to benefit from the rainwater. The distribution of rainfall throughout the season of 2010-2011, showed that only few rain storms had produced runoff, the quantities of runoff water will be lost and can't be used unless there is a reservoir to harvest the water of the storms. In such a case, the water can be used later. Thus Rainwater harvesting technique can be used in this area to overcome these difficulties. WMS was applied for each single rainfall storm for the five selected basins to find out the volume of water produced by the runoff that can be collected and stored in reservoirs. These reservoirs were previously carefully chosen.

The results showed that there were thirteen successful runoff events that had produced by thirteen rain storms along the season 2010-2011 in addition other three rain storms didn't produced runoff (Figures 7 and 8). Thus, among these thirteen runoff events, the minimum total harvested runoff volume from the total catchment areas of the five basins was $0.01 \times 10^{6} \mathrm{~m}^{3}$. This was produced by rain storm of $29.3 \mathrm{~mm}$ which took place on $15^{\text {th }}$ January, 2011 with $76^{\text {th }}$ day of starting the season (Figure 9). The above harvested runoff volume were distributed as follows: $123.3,4193.8,863.4,8511.0$ and $0.0\left(\mathrm{~m}^{3}\right)$ that were captured from catchment areas of basin No.1 to No. 5 and stored in the reservoir No. 1 to No. 5 respectively.

All five basins have identical characteristics, and in such a case, the most influential factors that affect the harvested runoff volume were the size of the catchment area, its slope, antecedent moisture conditions, and the curve number value. These factors work together to produce a certain runoff. However, combination of some conditions within the basin such as its area is large and the slope is low, then for small rainfall depth and low antecedent moisture conditions there will be no runoff. This was exactly the case at basin No. 5 under the above rain storm, where the runoff was zero due to the large area $\left(31.66 \mathrm{Km}^{2}\right)$, relative to other basins, and low slope (6.8\%) (Table 1) in addition to the low AMC (8.7 mm) (Figure 6) where the rainfall was completely stopped through three previous days. In such a case, infiltration is enhanced in addition to the effect of low value of $\mathrm{CN}$ add to the above factors then the result, certainly will be zero runoff where the runoff is very sensitive for $\mathrm{CN}$ value which reflect the hydrologic condition of the catchment area.

It should be noted that basin No. 5 has the smallest value of curve number (Table 3), due to having maximum area of crop, and minimum area of rock relative to the other basins in addition to some area of forest all that lead to a minimum curve number (76.9 and 88.5 for normal and wet conditions respectively).

The results indicated that rainfall depth is not the only influential factors in RWH. As an example, the two rain storms, the first on $20^{\text {th }}$ April, $2011\left(171^{\text {st }}\right.$ day of starting the season was) had rainfall depth of $50.9 \mathrm{~mm}$ and produced $0.50 \times 10^{6} \mathrm{~m}^{3}$ of runoff (Figure 9), the second storm on $22^{\text {nd }}$ April, 2011 ( $173^{\text {rd }}$ day of starting the season) had rainfall depth of $39.8 \mathrm{~mm}$ and produced $3.53 \times$ $10^{6} \mathrm{~m}^{3}$ of runoff (Figure 9). The higher rain depth storm $(50.9 \mathrm{~mm})$ didn't produce larger runoff volume relative to the smaller rain depth storm $(39.8 \mathrm{~mm})$. This is belived to be due to the fact that the value of antecedent moisture conditions were equal to zero with the higher rain 


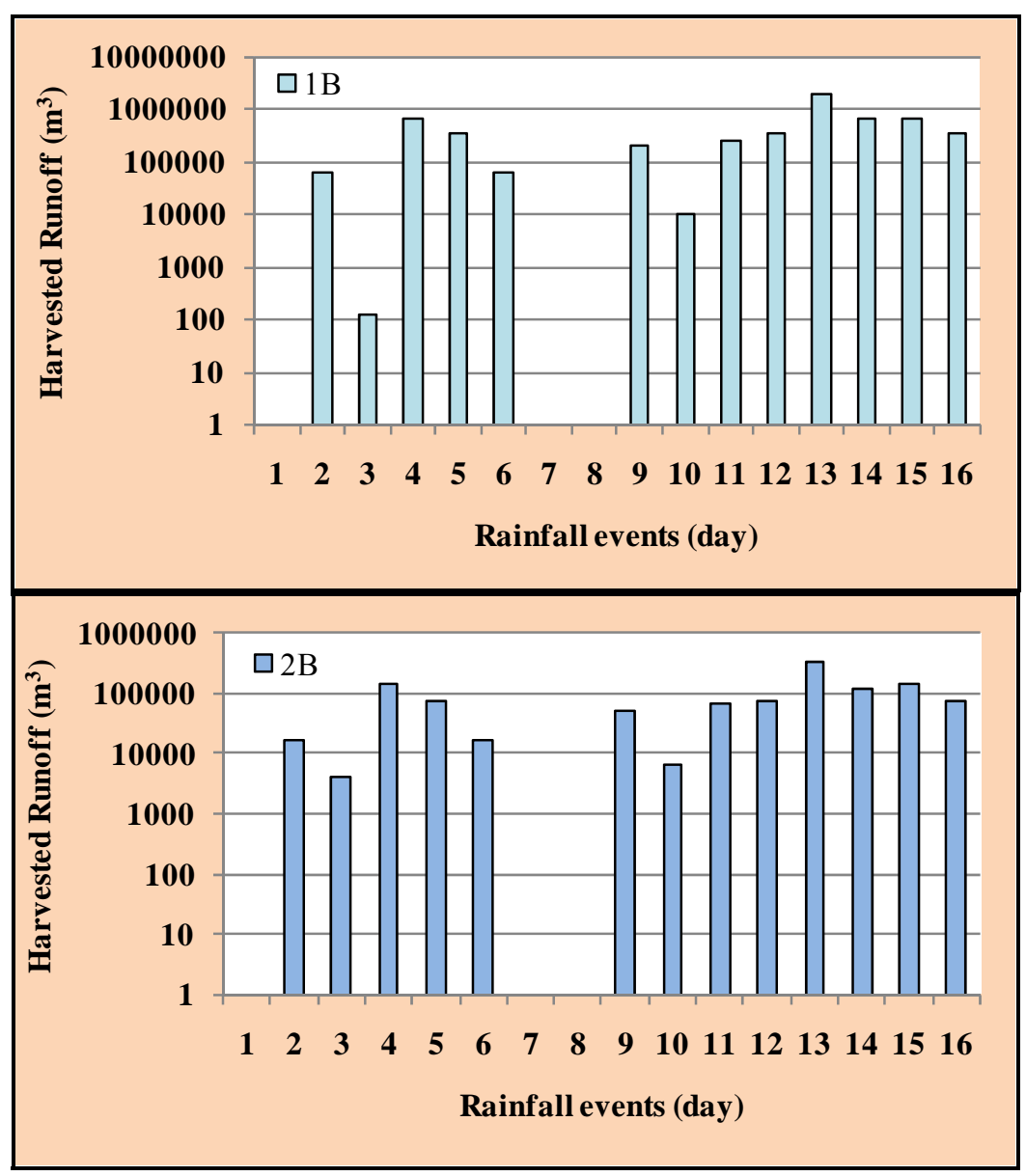

Figure 7. Daily runoff of the season 2010-2011 for basins 1B and 2B.

depth storm and this made the curve number to be in dry condition value which produce less volume amount of runoff, while the AMC was equal $68.3 \mathrm{~mm}$ with the smaller rain depth storm and this made the curve number to be in wet condition value which produce more volume of runoff.

The weak rainfall storms are very important for estimating the $\mathrm{CN}$ values, even if they didn't produce runoff. That is because they will keep antecedent moisture conditions in high value and prevent $\mathrm{CN}$ to fall to dry values. In the previous example, it was dry for seven continuous days where the antecedent moisture condition was zero before the start of the rain storm having the rain depth of (50.9 mm).

As mentioned above, the maximum total harvested runoff volume by the total catchment areas of the five basins was $3.53 \times 10^{6} \mathrm{~m}^{3}$ (Figure 9). This was produced by the rain storm of $39.8 \mathrm{~mm}$ depth of rain. The harvested runoff volume was captured by basins No. 1 to No. 5 as follow: 1928796.0, 312317.6, 157145.6, 580969.9 and $546925.8\left(\mathrm{~m}^{3}\right)$ respectively.

Again, the results indicated that, the influential factors (area, slope, $\mathrm{CN}$, and the AMC) can work together in a different direction to produce maximum runoff volume $\left(1928796.0 \mathrm{~m}^{3}\right)$ that was satisfied in basin No. 1 by the above rain storm (Figure 7). This can be explained the existence of high value of antecedent moisture conditions $(68.3 \mathrm{~mm})$ that led to wet the ground surface of the basin which reduced the ability of infiltration. Furthermore, when the catchment area has a relatively high slope $(28.37 \%)$ then that will lead to decrease the opportunity time of infiltration, and produces more water for runoff. In addition to the above, the high wet curve number value of 90.2 also played an important role in the increase of the runoff volume in that basin.

The total harvested water in the selected basins (1 to 5) was 5.73, 1.07, 0.51, 2.0 and 1.41 million cubic meters respectively. Figures 7 and $\mathbf{8}$ show the distribution of the above runoff according to the rainfall events. The total annual harvested runoff by all the catchment area of the five basins ranged from 0.01 to 3.53 million cubic meters. Thus the total annual harvested runoff reached about 10.76 million cubic meters (Figure 9). The results showed that there was an effective quantity of annual runoff that can be stored in the suggested reservoirs sites which can be used for different purposes. Thus the imple- 


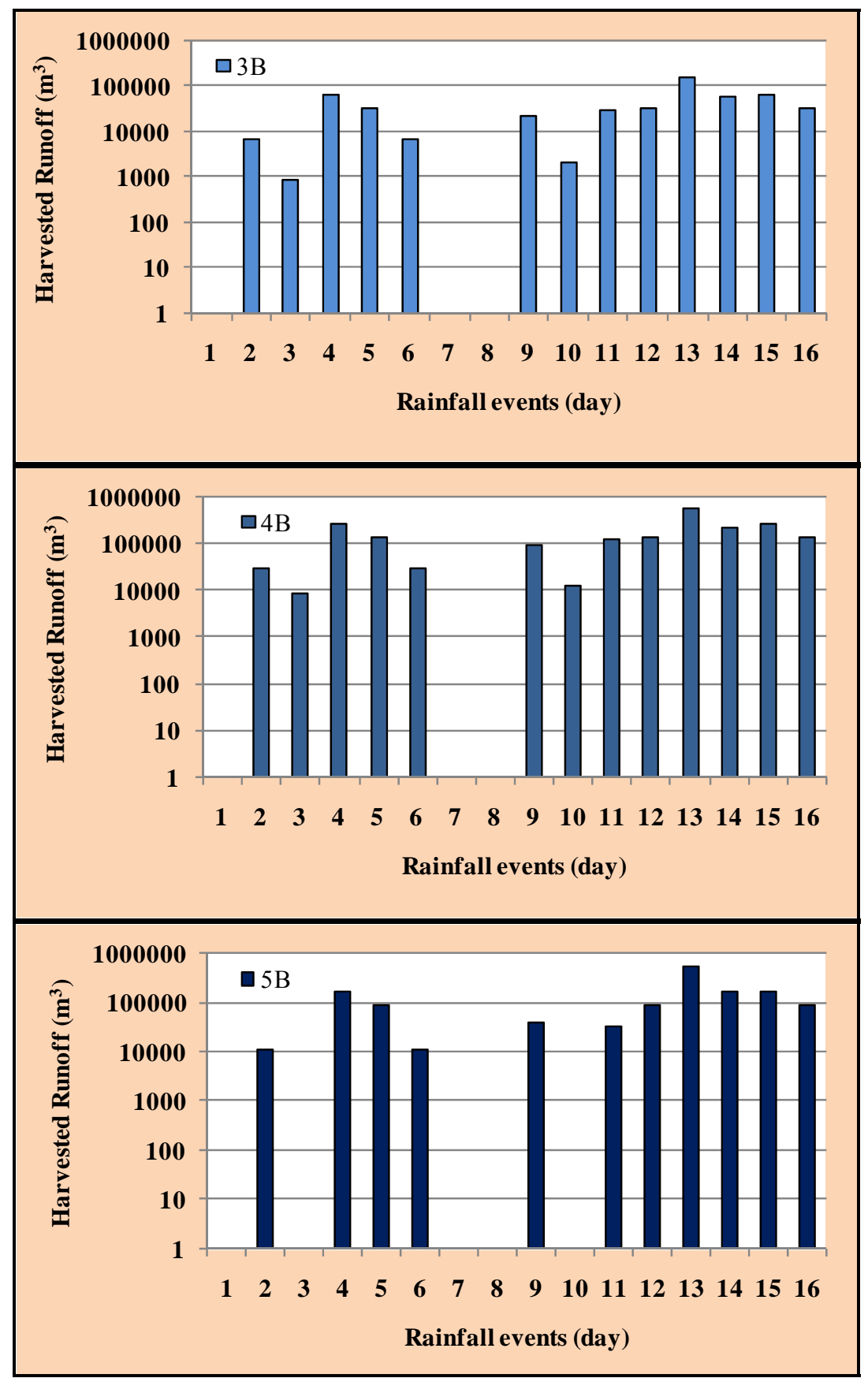

Figure 8. Daily runoff of the season 2010-2011 for basins 3B, 4B and 5B.

mentation of Macro RWH in the Northern Iraq, Sulaymaniyah Governorate gave encouraging results that can effectively contribute in solving the problem of water shortage.

\section{CONCLUSIONS}

Kurdistan Region (KR) of Iraq including Sulaymaniyah governorate had suffered from the drought period during the seasons 2007-2008 and 2008-2009 that affected the human and economic activities of the region.
Rainwater harvesting technique was tested to see its ability to help in overcoming such problem. Rainfall records representing the period 2002-2012 were studied and an average season (2010-2011) was selected to test the efficiency of RWH Technique.

The results showed that the harvested runoff volume ranged from $0.01 \times 10^{6}$ to $3.53 \times 10^{6} \mathrm{~m}^{3}$ in that year. Thus the total annual harvested runoff reached about $10.76 \times 10^{6} \mathrm{~m}^{3}$. These quantities can contribute in solving the problem of water shortage within the region. 


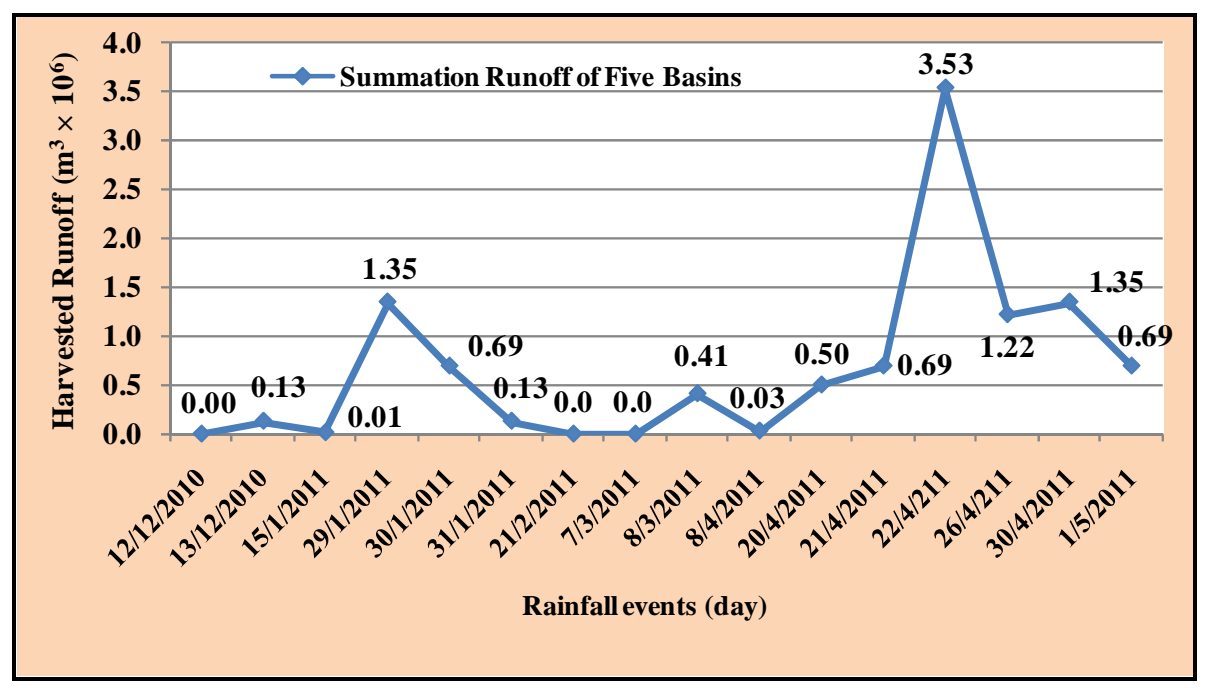

Figure 9. Total annual runoff of the season 2010-2011 for all five basins.

It was also noticed that the depth of rainfall alone was not an effective factor. There are other factors that influence the quantity of the harvested water such as: the size of the catchment area, its slope, antecedent moisture conditions (AMC), and the curve number value $(\mathrm{CN})$.

\section{ACKNOWLEDGEMENTS}

The authors would like to thank Mrs. Semia Ben Ali Saadaoui of the UNESCO-Iraq for her encouragement and support. Deep thanks go to the Ministry of Higher Education and Scientific Research, Baghdad, Iraq; Mosul university, Mosul, Iraq for their support. Thanks for Sulaymaniyah University for providing some related data. The research presented has been financially supported by Luleå University of Technology, Sweden and by "Swedish Hydropower Centre-SVC" established by the Swedish Energy Agency, Elforsk and Svenska Kraftnät together with Luleå University of Technology, The Royal Institute of Technology, Chalmers University of Technology and Uppsala University. Their support is highly appreciated.

\section{REFERENCES}

[1] Al-Ansari, N.A., (1998) Water resources in the Arab countries: Problems and possible solutions. UNESCO International Conference (Water: A loomingcrisis), Paris, 367376.

[2] Al-Ansari, N.A. (2013) Management of water resources in Iraq: Perspectives and prognoses. Journal of Engineering, 5, 667-684.

[3] Al-Ansari, N.A. and Knutsson, S. (2011) Toward prudent management of water resources in Iraq. Journal of Advanced Science and Engineering Research, 1, 53-67.

[4] UNDP (United Nations Development Programmer Iraq) (2011) Drought impact assessment, recovery and mitigation framework and regional project design in Kurdistan region.

[5] United Nations (2010) Water resources management white paper. United Nations assistance mission for Iraq, United Nations Country Team in Iraq, 20.

[6] Hamdy, A. (2013) Water crisis and food security in the Arab world: The future challenges. http://gwpmed.org/files/IWRM-Libya/Atef $\% 20 \mathrm{Hamdy} \%$ 20AWC.pdf

[7] Prinz, D. and Singh, A.K. (2000) Water resources in arid regions and their sustainable management. Special Issue on Research, Annals of Arid Zone, 39, 1-8.

[8] Oweis, T. and Hachum, A. (2006) Water harvesting and supplemental irrigation for improved water productivity of dry farming systems in West Asia and North Africa. Journal of Agricultural Water Management, 80, 57-73.

[9] Prinz, D. (1996) Water harvesting: Past and future. In: Pereira, L.S., Ed., Sustainability of Irrigated Agriculture. Proceedings, NATO Advanced Research Workshop, Vimeiro, 21-26.03, Balkema, Rotterdam, 135-144.

[10] Al-Ansari, N.A., Alroubai, A. and Knutsson (2012) Bathymetry and sediment survey for two old water harvesting schemes, Jordan. Journal of Earth Science and Geotechnical Engineering, 2, 13-23.

[11] Al-Ansari, N.A., Alroubai, A. and Knutsson, S. (2012) Sedimentation rates in two water harvesting schemes at the jordanian badia. Journal of Ecology and Environmental Sciences, 3, 82-86.

[12] Al-Ansari, N.A., Al-Hanbaly, M. and Knutsson, S. (2013) Hydrology of the most ancient water harvesting schemes. Journal of Earth Science and Geotechnical Engineering, 3, 15-25.

[13] Prinz, D. and Singh, A.K. (2000) Technological potential for improvements of water harvesting study for the world commission on dams, Cape Town, South Africa (Report: Dams and Development).

[14] Siegert, K. (1994) Introduction to water harvesting: Some basic principles for planning, design and monitoring. Water Harvesting for Improved Agricultural Production. Proceedings of the FAO Expert Consultation, FAO, Cairo, Rome. 
[15] Prinz, D. (1996) Water harvesting-History, techniques trends. Z. f. Bewaesserungswirtschaft31, 1, 64-105.

[16] Critchley, W. and Siegert, C. (1991) Water Harvesting Manual. FAO Paper AGL/MISC/17/91, FAO, Rome.

[17] Boers, T.M. and Ben-Asher, J. (1982) A review of rainwater harvesting. Agriculture Water Managem, 5, 145-158.

[18] Zakaria, S., Al-Ansari, N.A., Knutsson, S. and Ezz-Aldeen, M., (2012) Rainwater harvesting and supplemental irrigation at northern sinjar mountain, Iraq. Journal of Purity, Utility Reaction and Environment, 1, 121-141.

[19] Zakaria, S., Al-Ansari, N.A., Knutsson, S. and Ezz-Aldeen, M. (2012) Rainwater harvesting at eastern Sinjar mountain, Iraq. Journal of Geoscience Research, 3, 100108.

[20] Zakaria, S., Al-Ansari, N.A. and Knutsson, S. (2013) Rainwater harvesting using recorded and hypothetical rainfall data scenarios. Journal of Earth Sciences and Geotechnical Engineering, 3, 21-42.

[21] Zakaria, S., Al-Ansari, N.A. and Knutsson, S. (2013) Wheat yield scenarios for rainwater harvesting at Northern Sinjar Mountain, Iraq. Journal of Natural Science, 5, 10571068.

[22] Al-Ansari, N.A., Ezz-Aldeen, M., Knutsson, S. and Zakaria, S. (2013) Water harvesting and reservoir optimization in selected areas of south Sinjar Mountain, Iraq, Accepted for publication in ASCE. Journal of Hydrologic Engineering.

[23] Miriti, J.M., Esilaba, A.O., Bationo, A., Cheruiyot, H.K. Kathuku, A.N. and Wakaba, P. (2011) Water harvesting and integrated nutrient management options for maizecowpea production in semi-arid Eastern Kenya. Journal of Biomedical and Life Sciences, Part 2, 473-480.

[24] Bakari, A.H., Mahoo, H.F. and Hatibu, N. (1998) Perormance of maize under gully flow supplementary irrigation. In: Makungu, P.J., Mahoo, H.F., Silayo, V.C.K. and Mdemu, M., Eds., A Proceedings of Tanzania Society of Agricultural Engineers, 8, 20-42.

[25] Gowing, J.W., Mahoo, H.F., Mzirai, O.B. and Hatibu, N. (1999) Review of water harvesting techniques and evidence for their use in semi-arid Tanzania. Tanzania Journal of Agricultural Science, 2, 171-180.

[26] Mzirai, O. and Tumbo, S. (2010) Macro-catchment rainwater harvesting systems: Challenges and opportunities to access runoff. Journal of Animal \& Plant Sciences, JAPS, 7, 789-800.

[27] Bruins, H.J., Evenari, M. and Nessler, U. (1986) Rainwater-harvesting agriculture for food production in arid zones the challenge of the African famine. Applied Geography, 6, 13-32.

[28] Fox, P. and Rockstrom, J. (2003) Supplemental irrigation for dry-spell mitigation of rainfed agriculture in the Sahel. Agricultural Water Management, 61, 29-50.

[29] Hatibu, N., Young, M.D.B., Gowing, J.W., Mahoo, H.F. and Mzirai, O.B. (2003) Developing improved dryland cropping systems for maize in semi-arid Tanzania. Part 1:
Experimental evidence for the benefits of rainwater harvesting. Experimental Agriculture, 39, 279-292.

[30] Zakaria, S., Nadhir Al-Ansari, Yaseen, T., Mustafa, Payman Suhbat Ahmad, Bahra, D.G. and Sven, K. (2013) Rainwater harvesting at Koysinjaq (Koya), Kurdistan region, Iraq. Journal of Earth Sciences and Geotechnical Engineering.

[31] Zakaria, S., Al-Ansari, N.A., Yaseen, T., Mustafa, M.D.J., Alshibli and Knutsson, S. (2013) Macro rain water harvesting network to estimate annual runoff at Koysinjaq (Koya) district, Kurdistan region of Iraq. Journal of Engineering.

[32] Ponce, V.M. and Hawkins, R.H. (1996) Runoff curve number: Has it reached maturity? ASCE Journal Hydrologic Engineering, 1, 11-19.

[33] Saber, M., Hamaguchi, T., Kojiri, T. and Tanaka, K. (2009) Spatiotemporal runoff features of hydrological modeling in arabian wadi basins through comparative studies. Annals of Disaster Prevention Research Institute, Kyoto University, Kyoto.

[34] Al-Zubi, J., Al-Zubi, Y. and Abubaker, S. (2010) Hydrology and water harvesting techniques of wadimuheiwir catchment area-the case study of Jordan. Journal of Applied Science, 10, 298-304.

[35] Šimák, P., (2009) Hydrological study of the ashibaram dam, PhD. Dissertation Royal Institute of Technology (KTH), Sweden.

[36] Williams, J.R. (1995) The EPIC model, Chapter 25. In Singh, V.P., Ed., Computer Models of Watershed Hydrology, Water Resources Publications, Highlands Ranch, CO.

[37] Neitsch, S.L., Arnold, J.G., Kiniry, J.R. and Williams, J.R. (2005) Soil and water assessments tool theoretical documentation, 102. http://swat.tamu.edu/media /1292/swat2005theory.pdf

[38] ASCE/EWRI Curve Number Hydrology Task Committee (2009) Curve number hydrology: State of the practice. In: Hawkins, R.H., Ward, T.J., Donald, E.W. and VanMullem, J.A., Eds., American Society of Civil Engineers, Reston, Virginia, 116.

[39] Mohammed H., (2013) Water harvesting in Erbil Governorate, Kurdistan region, Iraq Detection of suitable sites using Geographic Information System and Remote Sensing.", Master thesis, Lund University, Sweden.

[40] Al-Ansari, N.A., Zakaria, S., Mustafa, Y.T., Ahmad, P., Ghafour, B. and Knutsson, S. (2013) Development of water resources in Koya City, Iraq. 1st International Symposium on Urban Development of Koya, 16-17 December 2013, Koya University.

[41] Chow VenTe, Maidment, David, R., Mays and Larry, W. (1988) Applied Hydrology. McGraw Hill, 277.

[42] Buringh, P. (1960) Soils and soil conditions of Iraq. Ministry of Agriculture, Agricultural Research and Projects, Baghdad. 